Prepared for the U.S. Department of Energy

under Contract DE-AC05-76RL01830

\title{
2010 Ecological Survey of the Pacific Northwest National Laboratory Site
}
MA Chamness
CM Perry
JL Downs
SD Powell

February 2011

\section{Pacific Northwest}

NATIONAL LABORATORY

Proudly Operated by Battelle Since 1965 


\title{
DISCLAIMER
}

This report was prepared as an account of work sponsored by an agency of the United States Government. Neither the United States Government nor any agency thereof, nor Battelle Memorial Institute, nor any of their employees, makes any warranty, express or implied, or assumes any legal liability or responsibility for the accuracy, completeness, or usefulness of any information, apparatus, product, or process disclosed, or represents that its use would not infringe privately owned rights. Reference herein to any specific commercial product, process, or service by trade name, trademark, manufacturer, or otherwise does not necessarily constitute or imply its endorsement, recommendation, or favoring by the United States Government or any agency thereof, or Battelle Memorial Institute. The views and opinions of authors expressed herein do not necessarily state or reflect those of the United States Government or any agency thereof.

\author{
PACIFIC NORTHWEST NATIONAL LABORATORY \\ operated by \\ BATTELLE \\ for the \\ UNITED STATES DEPARTMENT OF ENERGY \\ under Contract DE-AC05-76RL01830
}

Printed in the United States of America
Available to DOE and DOE contractors from the Office of Scientific and Technical Information,
P.O. Box 62, Oak Ridge, TN 37831-0062;
ph: (865) 576-8401
fax: $(865) 576-5728$
email: reports@adonis.osti.gov

\begin{abstract}
Available to the public from the National Technical Information Service, U.S. Department of Commerce, 5285 Port Royal Rd., Springfield, VA 22161 ph: (800) 553-6847 fax: $(703) 605-6900$ email: orders@ntis.fedworld.gov online ordering: http://www.ntis.gov/ordering.htm
\end{abstract}

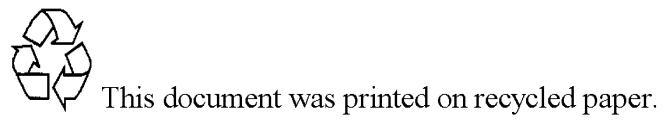

$(9 / 2003)$ 


\title{
2010 Ecological Survey of the Pacific Northwest National Laboratory Site
}

\author{
MA Chamness \\ CM Perry \\ JL Downs \\ SD Powell
}

February 2011

Prepared for

the U.S. Department of Energy

under Contract DE-AC05-76RL01830

Pacific Northwest National Laboratory

Richland, Washington 99352 


\section{Contents}

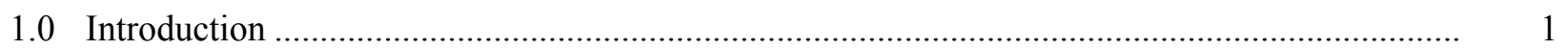

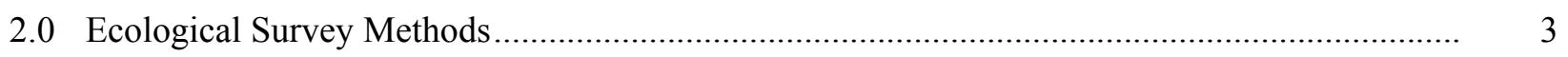

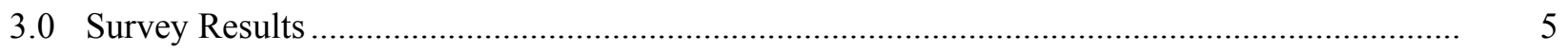

3.1 Baseline Survey of Upland Habitats ............................................................................ 5

3.2 Survey, Mapping, and Control of Noxious Weed Populations ......................................... 7

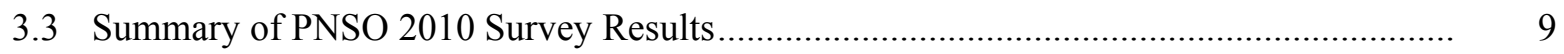

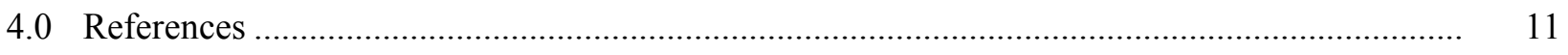

Appendix - List of Plant and Animal Species Observed on the PNNL Site .................................. A.1

\section{Figures}

1 Plant Communities Found on the Pacific Northwest National Laboratory Site ......................... 6

2 Location of Noxious Weeds Found and Areas Sprayed on the PNNL Site in 2010.................. 8

\section{Table}

1 Estimated Acreages of Noxious Weeds Occurring on the PNNL Site Treated in 2010 and Remaining to be Treated 


\subsection{Introduction}

The U.S. Department of Energy (DOE) Pacific Northwest Site Office (PNSO) oversees and manages the DOE contract for the Pacific Northwest National Laboratory (PNNL), a DOE Office of Science multiprogram laboratory located in Richland, Washington. PNSO is responsible for ensuring that all activities conducted on the PNNL Site comply with applicable laws, policies, and DOE orders.

The DOE Pacific Northwest Site Office Cultural and Biological Resources Management Plan (DOE/PNSO 2008) addresses the requirement for annual surveys and monitoring for species of concern and to identify and map invasive species. In addition to the requirement for an annual survey, proposed project activities must be reviewed to assess any potential environmental consequences of conducting the project. The assessment process requires a thorough understanding of the resources present, the potential impacts of a proposed action to those resources, and the ultimate consequences of those actions.

The PNNL Site is situated on the southeastern corner of the DOE Hanford Site, located at the north end of the city of Richland in south-central Washington. The site is bordered on the east by the Columbia River, on the west by Stevens Drive, and on the north by the Hanford Site 300 Area (Figure 1). The environmental setting of the PNNL Site is described in Larson and Downs (2009). There are currently two facilities on the PNNL Site: the William R. Wiley Environmental Molecular Sciences Laboratory (EMSL), and the recently completed Physical Sciences Facility (PSF).

This report describes the results of the annual survey of the biological resources found on the undeveloped portions of the PNNL Site in 2010. A brief description of the methods PNNL ecologists used to conduct the surveys and the results of the surveys are presented. Actions taken to fully delineate noxious weed populations discovered in 2009 and efforts in 2010 to control those weeds also are described. The Appendix provides a list of plant and animal species identified on the PNNL Site. 


\subsection{Ecological Survey Methods}

The primary objective of the field surveys was to determine the occurrence of plant and animal species protected under the Endangered Species Act of 1973, candidates for such protection, species listed as threatened, endangered, candidate, sensitive, or monitor species by the state of Washington (WDFW 2010), and species protected under the Migratory Bird Treaty Act. PNNL ecologists performed pedestrian and visual reconnaissance of the PNNL Site in April, June and July 2010. Results of previous field surveys are summarized in Larson and Downs (2009).

A second objective of the annual surveys involves documenting the current condition of biological resources and inventorying the wildlife and plant species found on the PNNL site. During pedestrian surveys of the site, any occurrences of those plant species designated as noxious weeds by the Washington State Noxious Weed Control Board were documented, and coordinates were recorded to delineate the locations. During 2010, PNNL ecologists worked with facilities and environmental management staff to identify and prioritize areas where spraying was conducted to control the largest infestations of noxious weeds (RCW 17.10.140) on the PNNL site. Areas to be sprayed were surveyed and flagged by ecologists in the field. PNNL ecologists worked with the facilities and maintenance staff to aid in recognition of targeted weeds, and provided support during hand-spraying of targeted plants.

Field surveys were conducted across the PNNL Site (except in those areas where construction was in progress) during April, June and July, 2010. These consisted of pedestrian surveys to observe and document the vegetation and wildlife that occur on the site. During June, an early morning pedestrian survey was conducted in the riparian zone of the site to document breeding birds. As part of these survey efforts, a more detailed review of the riparian area was performed, locations of noxious weed species were mapped, and staff reviewed and monitored efforts initiated to control noxious weed concentrations in May. 


\subsection{Survey Results}

Biological surveys conducted on the PNNL Site during the spring and summer of 2010 focused on three main objectives:

- Survey of the upland habitats

- Survey, mapping and control of noxious weed populations

- Initial survey of the riparian (riverside) habitat

Results of the 2010 surveys are presented in this report. Additional information on the habitats and biological resources occurring on the PNNL site is described in Larson and Downs (2009).

\subsection{Baseline Survey of Upland Habitats}

The upland portions of the PNNL site support plant communities dominated primarily by big sagebrush (Artemisia tridentata) and perennial bunchgrasses (Figure 1). Antelope bitterbrush (Purshia tridentata) and gray and green rabbitbrush (Ericameria nauseosa and Chrysothamnus viscidiflorus) are also common native shrubs within the site. The most common perennial native bunchgrass in the area is Sandberg's bluegrass (Poa secunda), occurring with needle-and-thread grass (Hesperostipa comata) and Indian ricegrass (Achnathrum hymenoides). The non-native cheatgrass (Bromus tectorum) also occurs in all plant communities in the PNNL Site. Common native forb species include Carey's balsamroot (Balsamorhiza careyana), long-leaved phlox (Phlox longifolia), yarrow (Achillea millefolium), and turpentine springparsley (Cymoterus terebinthinus). Common non-native forbs include tumblemustard (Sisymbrium altissimum), Russian thistle (Salsola tragus) and several species listed as Class B noxious weeds, including rush skeletonweed (Chondrilla juncea), Russian knapweed (Acroptilon repens), and yellow star-thistle (Centaurea solstitialis). The weeds listed above are all classified as Class B noxious weeds by the Washington State (WAC 16-750) and are designated for control and/or containment.

Evidence of use by coyote (Canis latrans), mule deer (Odocoileus hemionus), American badgers (Taxidea taxus) and unidentified rabbits and small mammal species was observed throughout the area. A snakeskin from an unidentified snake was also found. A wide variety of migratory bird species were observed in the area. Species that were observed nesting or are likely to nest in the area include, but are not limited to mourning doves (Zenaida macroura), lark sparrows (Chondestes grammacus), horned larks (Eremophila alpestris), California quail (Callipepla californica), western meadowlarks (Sturnella neglecta).

In addition to survey data collected for upland migratory bird species, anecdotal observations were made documenting a bank swallow (Riparia riparia) colony using a stockpile of soil on the construction site for the Physical Sciences Facility in late June. Bank swallows excavate small diameter holes into firm, banked soils to build their nests and raise their young. This observation was not made as part of the formal surveys of the PNNL Site. In early July, a PNNL biologist noticed that a major portion of the stockpiled soil at the Physical Sciences Facility construction site had been removed for landscaping, which resulted in the partial destruction of the bank swallow habitat within the stockpiled soil. As a result, on July 8, 2010, the event was self-reported to the U.S. Fish \& Wildlife Service (USFWS) by PNNL. The issue is part of an ongoing USFWS investigation. 


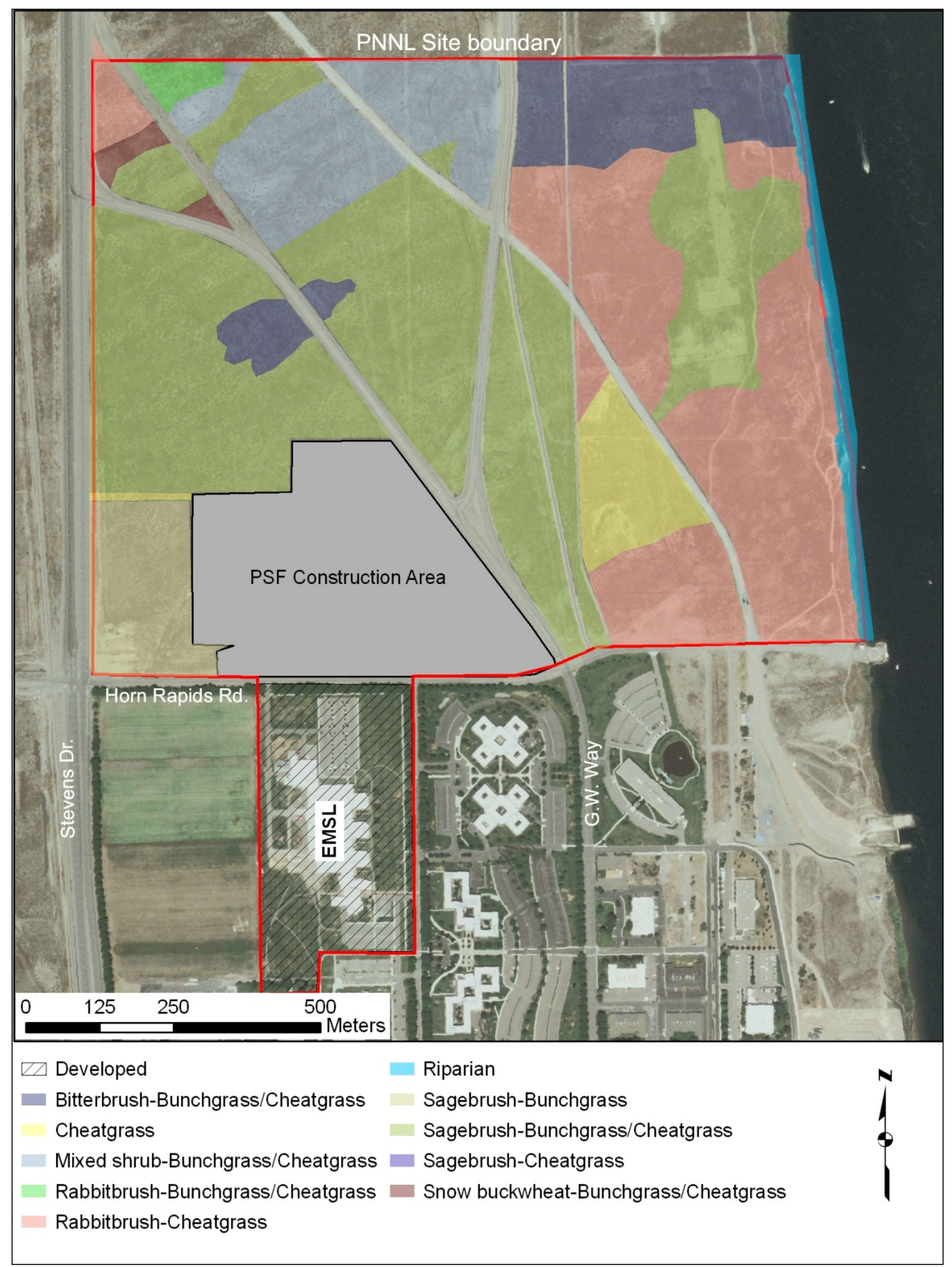

Figure 1. Plant Communities Found on the Pacific Northwest National Laboratory Site 


\subsection{Survey, Mapping, and Control of Noxious Weed Populations}

Several species of noxious weeds, including Russian knapweed (Acroptilon repens), rush skeletonweed (Chondrilla juncea), yellow star-thistle (Centaurea solstitialis) and diffuse knapweed (Centaurea diffusa) were identified on the PNNL Site in August 2009. In April 2010, Ecology group staff began mapping the locations of these noxious weed populations, completing the mapping in August (Figure 2). As an initial control strategy, staff from PNNL Facilities \& Operations, Environmental Services, and the Ecology group focused on hand-spraying herbicides targeting the individual plants within the largest populations of rush skeletonweed and the smaller patches of yellow star-thistle. This type of treatment in 2010 is intended to significantly reduce the population and reduce seed production.

Maintenance staff with current applicators license for Washington State, sprayed the herbicide Milestone (along with a water conditioner, drift control and sticking agents, and blue dye for visibility) using backpack sprayers on May 11 and on May 12, covering a total of $\sim 7$ acres over the two days. Three staff with backpack sprayers worked on June 12 to spray $\sim 6$ more acres. In addition, staff revisited approximately 2 acres to hit plants missed during the earlier spraying. The Milestone label and MSDS can be found at http://www.cdms.net/manuf/1prod.asp?pd=8113\&lc $=0$.

Observations during the 2010 growing season indicated that Milestone appears to be effective in killing rush skeletonweed, yellow star-thistle, and diffuse knapweed when the plants are thoroughly sprayed. If the plants are lightly sprayed, the plants appear to be damaged, but may not be killed.

We estimated the acreage remaining to be sprayed based on mapping with global positioning systems (GPS) in the field. Large, dense areas of noxious weeds were mapped as polygons with a GPS. Smaller patches were identified by recording a point location, and estimating the areal extent based on the comments recorded at each point.

Altogether, we estimate approximately 16.3 additional acres will require herbicide treatment to control noxious weeds in 2011. In addition, the 13 acres treated in 2010 primarily for rush skeletonweed will need to be resurveyed to identify any new seedlings and any plants missed or not killed during the 2010 treatment. Table 1 provides a list of noxious weed species and acreages for each.

Approximately 4 acres of the 16.3 acres yet to be treated are dominated by Russian knapweed and another 1.7 acres contain a mixture of Russian knapweed and rush skeletonweed. Russian knapweed likely will be treated using a different herbicide and/or method than that used on the other noxious weeds to ensure control of this species. Approximately 0.8 acre containing a concentration of Russian knapweed is located near the river in an area that may be of concern to tribes. Spraying in that area will need to be coordinated with cultural resource staff as well as ecological resource staff. 


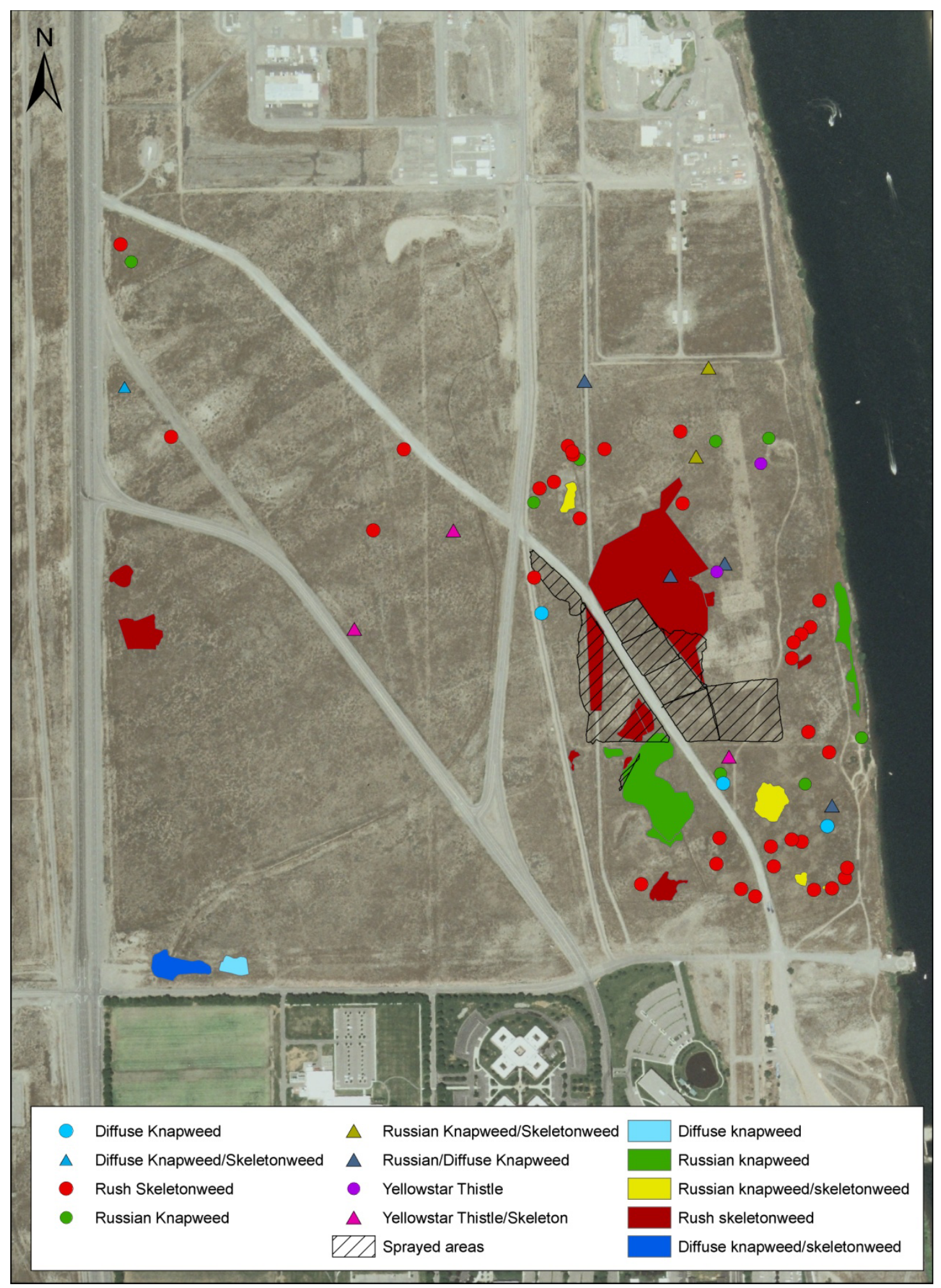

Figure 2. Location of Noxious Weeds Found and Areas Sprayed on the PNNL Site in 2010 
Table 1. Estimated Acreages of Noxious Weeds Occurring on the PNNL Site Treated in 2010 and Remaining to be Treated

\begin{tabular}{|c|c|c|}
\hline Species & $\begin{array}{c}\text { Acres Treated in } \\
2010\end{array}$ & $\begin{array}{c}\text { Acres Remaining to } \\
\text { be Treated }\end{array}$ \\
\hline Rush skeletonweed & 13 & 10.1 \\
\hline Diffuse knapweed & 0 & 0.3 \\
\hline Yellow star-thistle & 0 & 0.2 \\
\hline Russian knapweed & 0 & 4 \\
\hline $\begin{array}{l}\text { Rush skeletonweed and Russian } \\
\text { knapweed mixed }\end{array}$ & 0 & 1.7 \\
\hline Total & 13 & 16.3 \\
\hline
\end{tabular}

\subsection{Summary of PNSO 2010 Survey Results}

As described in survey results documented for 2009 and in this report, the PNNL Site contains various types of shrub-steppe and riparian vegetation that have been invaded by several species of Class B noxious weeds. Although noxious weeds are present in the area, the site continues to provide habitat for a variety of wildlife (Appendix) and plants (101 species). Surveys documented at least 31 different species of birds, and noted evidence of more than 8 mammals using the available habitat.

The invasive and noxious weeds pose a continuing threat to the ecological integrity of the habitat. Herbicide applications in 2010 were successful in providing an initial level of control for populations of noxious weed species; however, additional applications in the spring of 2011, and possibly in the autumn will be required to target the different species of noxious weeds, and make progress in eradicating these plants from the PNNL site. Surveys and spraying to detect and control these species will likely need to be continued over a several year period.

The initial invasion of the noxious weeds onto the PNNL site appears to be related to the roads traversing the site. These roads will continue to provide an avenue for introduction of weed seeds onto the site, and the roadways and adjacent habitat should be surveyed annually to detect new invasions or individuals. In addition, biological control agents may also be helpful in controlling Russian knapweed, and the feasibility of adding biological controls as part of an integrated approach to weed control should be further investigated. 


\subsection{References}

DOE/PNSO. 2008. Pacific Northwest Site Office Cultural and Biological Resources Management Plan. DOE/PNSO Guide 11, Rev. 2, U.S. Department of Energy, Pacific Northwest Site Office, Richland, Washington.

Endangered Species Act of 1973. 1973. Public Law 93-205, as amended, 16 USC 1531 et seq.

Larson KB and JL Downs. 2009. 2009 Baseline Ecological Survey: Pacific Northwest National Laboratory Site. PNNL-18939, Pacific Northwest National Laboratory, Richland, Washington.

Migratory Bird Treaty Act. 1918. Chapter 128, as amended, 16 USC 703-712.

RCW 17.10.140. "Owner's Duty to Control Spread of Noxious Weeds." Revised Code of Washington, Olympia, Washington. Available at http://apps.leg.wa.gov/RCW/default.aspx?cite=17.10.140 (November 2009).

WAC 16-750. "State Noxious Weed List and Schedule of Monetary Penalties." Washington Administrative Code, Olympia, Washington. Available at http://apps.leg.wa.gov/WAC/default.aspx?cite=16-750 (December 2010).

Washington Department of Fish and Wildlife (WDFW). 2010. "Species of Concern in Washington State." Available at http://wdfw.wa.gov/wlm/diversty/soc/soc.htm. 


\section{Appendix}

\section{List of Plant and Animal Species}

Observed on the PNNL Site 


\section{Appendix}

\section{List of Plant and Animal Species Observed on the PNNL Site}

\begin{tabular}{ll}
\hline & Plants \\
\hline Achillea millefolium & \\
\hline Achnatherum hymenoides & yarrow \\
\hline Acroptilon repens & Indian ricegrass \\
\hline Agoseris heterophylla & Russian knapweed \\
\hline Agropyron cristatum & annual mountain dandelion \\
\hline Ailanthus altissima & crested wheatgrass \\
\hline Allium schoenoprasum & tree-of-heaven \\
\hline Ambrosia acanthicarpa & chives \\
\hline Amsinckia lycopsoides & bur ragweed \\
\hline Artemisia campestris ssp. borealis var. scouleriana & fiddleneck \\
\hline Artemisia dracunculus & northern wormwood \\
\hline Artemisia lindleyana & tarragon \\
\hline Artemisia tridentata & Columbia River mugwort \\
\hline Asclepias speciosa & big sagebrush \\
\hline Asparagus officinalis & showy milkweed \\
\hline Astragalus caricinus & asparagus \\
\hline Balsamorhiza careyana & buckwheat milkvetch \\
\hline Bassia scoparia & Carey's balsamroot \\
\hline Bromus tectorum & kochia \\
\hline Centaurea diffusa & cheatgrass \\
\hline Centaurea solstitialis & diffuse knapweed \\
\hline Chaenactis douglasii & yellow starthistle \\
\hline Chondrilla juncea & hoary falseyarrow \\
\hline Chorispora tenella & rush skeletonweed \\
\hline Chrysothamnus viscidiflorus & blue mustard \\
\hline Comandra umbellata ssp. pallida & green rabbitbrush \\
\hline Convolvulus arvensis & bastard toadflax \\
\hline Crepis atribarba ssp. originalis & field bindweed \\
\hline
\end{tabular}




\begin{tabular}{|c|c|}
\hline \multicolumn{2}{|l|}{ Plants } \\
\hline Cryptantha circumscissa & matted cryptantha \\
\hline Cryptantha fendleri & Fendler's cryptantha \\
\hline Dalea ornata & western prairieclover \\
\hline Descurainia pinnata & western tansymustard \\
\hline Descurainia sophia & flixweed \\
\hline Draba verna & spring whitlowgrass \\
\hline Elymus elymoides ssp. elymoides & bottlebrush grass \\
\hline Elymus lanceolatus ssp. lanceolatus & thickspike wheatgrass \\
\hline Epilobium brachycarpum & tall willowherb \\
\hline Ericameria nauseosa ssp. nauseosa var. speciosa & gray rabbitbrush \\
\hline Erigeron filifolius & threadleaf fleabane \\
\hline Eriogonum niveum & snow buckwheat \\
\hline Eriogonum vimineum & broom buckwheat \\
\hline Erodium cicutarium & storksbill \\
\hline Gaillardia aristata & blanket flower \\
\hline Gilia sinuata & shy gilia \\
\hline Gratiola neglecta & American hedge-hyssop \\
\hline Grayia spinosa & spiny hopsage \\
\hline Gypsophila paniculata & baby's breath \\
\hline Hesperostipa comata & needle-and-thread grass \\
\hline Holosteum umbellatum & jagged chickweed \\
\hline Hymenopappus filifolius & Columbia cutleaf \\
\hline Hypericum perforatum & Klamath weed \\
\hline Lactuca serriola & prickly lettuce \\
\hline Layia glandulosa & white-daisy tidytips \\
\hline Lepidium perfoliatum & clasping pepperweed \\
\hline Leptodactylon pungens & prickly phlox \\
\hline Leymus cinereus & giant wildrye \\
\hline Logfia arvensis & field fluffweed \\
\hline Lomatium macrocarpum & bigseed desertparsley \\
\hline Machaeranthera canescens & hoary aster \\
\hline Malus pumila & apple \\
\hline Medicago sativa & alfalfa \\
\hline Melilotus officinalis & white sweetclover \\
\hline Mentzelia albicaulis & whitestem stickleaf \\
\hline Microsteris gracilis var. humilior & pink microsteris \\
\hline
\end{tabular}




\begin{tabular}{|c|c|}
\hline \multicolumn{2}{|c|}{ Plants } \\
\hline Morus alba & white mulberry \\
\hline Oenothera pallida & pale evening primrose \\
\hline Opuntia polyacantha & starvation pricklypear \\
\hline Phacelia hastata & whiteleaf scorpionweed \\
\hline Phacelia linearis & threadleaf scorpionweed \\
\hline Phalaris arundinacea & reed canarygrass \\
\hline Phlox longifolia & longleaf phlox \\
\hline Plantago lanceolata & English plantain \\
\hline Plantago patagonica & indian wheat \\
\hline Poa bulbosa & bulbous bluegrass \\
\hline Poa secunda & Sandberg's bluegrass \\
\hline Polygonum convolvulus & climbing bindweed \\
\hline Prunus virginiana var. melanocarpa & chokecherry \\
\hline Pseudognaphalium stramineum & cottonbatting cudweed \\
\hline Pseudoroegneria spicata & bluebunch wheatgrass \\
\hline Psoralidium lanceolatum & dune scurfpea \\
\hline Pteryxia terebinthina var. terebinthina & turpentine springparsley \\
\hline Purshia tridentata & bitterbrush \\
\hline Robinia pseudo-acacia & black locust \\
\hline Rosa woodsii var. ultramontana & Woods' rose \\
\hline Rubus discolor & Himalayan blackberry \\
\hline Rumex salicifolius var. mexicanus & willow dock \\
\hline Rumex venosus & winged dock \\
\hline Salix exigua & coyote willow \\
\hline Salsola tragus & Russian thistle \\
\hline Sisymbrium altissimum & Jim Hill's tumblemustard \\
\hline Sphaeralcea munroana & Munro's globemallow \\
\hline Sporobolus cryptandrus & sand dropseed \\
\hline Stephanomeria paniculata & stiff wirelettuce \\
\hline Tragopogon dubius & yellow salsify \\
\hline Tribulus terrestris & puncture vine \\
\hline Triteleia grandiflora var. grandiflora & Douglas' clusterlily \\
\hline Ulmus pumila & Siberian elm \\
\hline Vulpia microstachys & small sixweeks \\
\hline Vulpia octoflora & slender sixweeks \\
\hline
\end{tabular}




\begin{tabular}{|c|c|}
\hline \multicolumn{2}{|c|}{ Birds } \\
\hline Actitis macularia & spotted sandpiper \\
\hline Agelaius phoeniceus & red-winged blackbird \\
\hline Ardea herodias & great blue heron \\
\hline Callipepla californica & California quail \\
\hline Carduelis tristis & American goldfinch \\
\hline Carpodacus mexicanus & house finch \\
\hline Chondestes grammacus & lark sparrow \\
\hline Chordeiles minor & common nighthawk \\
\hline Columba livia & rock dove \\
\hline Corvus brachyrhynchos & American crow \\
\hline Corvus corax & common raven \\
\hline Eremophila alpestris & horned lark \\
\hline Hirundo pyrrhonota & cliff swallow \\
\hline Hirundo rustica & barn swallow \\
\hline Icterus galbula & Bullock's oriole \\
\hline Larus californicus & California gull \\
\hline Mergus merganser & common merganser \\
\hline Numenius americanus & long-billed curlew \\
\hline Pandion haliaetus & osprey \\
\hline Passer domesticus & house sparrow \\
\hline Pelecanus erythrorhynchos & American white pelican \\
\hline Pica pica & black-billed magpie \\
\hline Riparia riparia & bank swallow \\
\hline Sterna paradisaea & arctic tern \\
\hline Sturnella neglecta & western meadowlark \\
\hline Sturnus vulgaris & European starling \\
\hline Turdus migratorius & American robin \\
\hline Tyrannus tyrannus & eastern kingbird \\
\hline Tyrannus verticalis & western kingbird \\
\hline Unidentified bird & Unidentified bird \\
\hline Zenaida macroura & mourning dove \\
\hline Zonotrichia leucophrys & white-crowned sparrow \\
\hline
\end{tabular}




\begin{tabular}{ll}
\hline & Animals \\
\hline Canis latrans & coyote \\
Castor canadensis & beaver \\
Erethizon dorsatum & porcupine \\
Lepus californicus & black-tailed jackrabbit \\
Odocoileus hemionus & mule deer \\
Sylvilagus nuttallii & mountain cottontail \\
Taxidea taxus & badger \\
Thomomys talpoides & northern pocket gopher \\
Unidentified/Unlisted herpetofauna & \\
Unidentified/Unlisted mammal & \\
Unidentified small mammal & \\
\hline
\end{tabular}




\section{Distribution}

No. of

Copies

ONSITE

2 DOE Pacific Northwest Site Office

TL Aldridge

TP Pietrok
No. of

Copies

4 Pacific Northwest National Laboratory

SS Allen

J2-33

CM Anderson

MA Chamness

SD Cooke

EG Damberg

JL Downs

JA Lettau

KM McDonald

RD Sharp

MJ Stephenson

RS Weeks
(PDF)

(PDF)

(PDF)

(PDF)

(PDF)

K4-35

P7-28

J4-50

(PDF)

(PDF)

Distr.1 


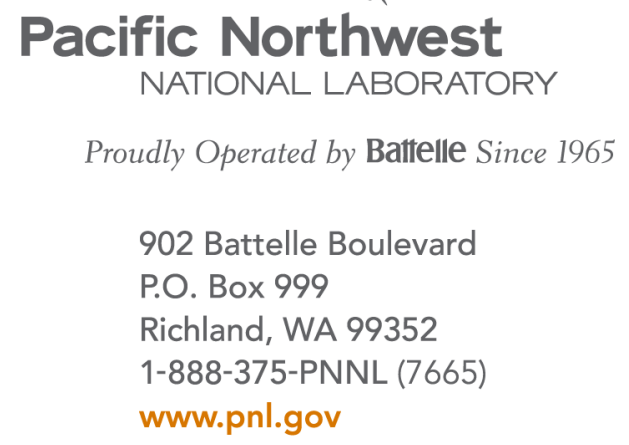

Pacific Northwest

NATIONAL LABORATORY

Proudly Operated by Battelle Since 1965

902 Battelle Boulevard

P.O. Box 999

Richland, WA 99352

1-888-375-PNNL (7665)

www.pnl.gov 